\title{
Current perspectives on tree nut allergy: a review
}

This article was published in the following Dove Press journal: Journal of Asthma and Allergy

\section{Tamar Weinberger Scott Sicherer}

The Elliot and Roslyn Jaffe Food Allergy Institute, Division of Allergy and Immunology, Kravis Children's Hospital, Department of Pediatrics, Icahn School of Medicine at Mount Sinai, New York, NY, USA
Correspondence: Tamar Weinberger The Elliot and Roslyn Jaffe Food Allergy Institute, Division of Allergy and Immunology, Kravis Children's Hospital, Department of Pediatrics, Icahn School of Medicine at Mount Sinai, I Gustave L Levy Place, Box II 98, New York, NY 10029, USA

$\mathrm{Tel}+|2| 224 \mid 5548$

Fax + I $212426 \mid 902$

Email Tamar.weinberger@mountsinai.org

\begin{abstract}
Tree nut $(\mathrm{TN})$ allergy is common and often severe. It has become an important health concern as availability and consumption have increased. Prevalence varies by age and geographic region and appears to have increased in children. Accidental ingestion of TNs is common. Unfortunately, there is a lower likelihood of resolution of $\mathrm{TN}$ allergy, roughly $10 \%$. TN-specific skin tests and serum immunoglobulin E levels can help aid in the diagnosis of TN allergy, but a careful medical history is important because a positive test in isolation is not typically diagnostic. Component-resolved diagnostic tests are being increasingly utilized and may improve accuracy. Management consists of strict avoidance of the causal nut(s) and prompt treatment of symptoms upon accidental exposure. A specific consideration with regard to the management of TN allergy is the decision to avoid all TNs or only the TNs to which a patient is clinically allergic. There are currently no data on the primary or secondary prevention of TN allergy. Treatment strategies are being evaluated.
\end{abstract}

Keywords: food allergy, anaphylaxis, food allergens, food hypersensitivity, cross reactivity, component resolved diagnostics

\section{Introduction}

Allergies to tree nuts (TNs) are common and have become an important health concern as availability has increased. ${ }^{1}$ TNs, as a group, are one of the eight most common allergens, and allergic reactions to them can be severe. ${ }^{2} \mathrm{TN}$ availability has increased both in the raw form and within processed foods and bakery products; TN utilization has increased by 2.3 pounds per capita from 1980 to $2015 .{ }^{3}$ Research has shown that the consumption of nuts has positive cardiovascular effects, such as decreasing cholesterol, triglycerides, and fasting blood glucose, and this has encouraged consumption. ${ }^{4,5}$

Botanically, TNs are defined as a dry fruit composed of an inedible hard shell and a seed. ${ }^{6}$ However, the term "TN" is commonly used to describe any nut coming from a tree, and this includes foods that do not meet the botanical definition. Nine nuts account for the majority of allergies to TNs, including walnut, almond, pistachio, cashew, pecan, hazelnut, macadamia, Brazil nut, and pine nut. ${ }^{6}$ For the purpose of labeling laws, the US Food and Drug Administration (FDA) additionally considers the following to be TNs: beechnut, butternut, chestnut, chinquapin, coconut, ginkgo nut, hickory nut, lychee nut, pili nut, and shea nut. ${ }^{7}$ A report from the National Academies of Sciences recommends that these nuts be removed from this list since there are little data on them and they uncommonly cause allergic reactions. ${ }^{8}$ For the purpose of this review, we will focus on the nine most common TNs that cause allergic reactions, and we do not extensively discuss peanut allergy (a legume). submit your manuscript Dovepress if in $>$ http://dx.doi.org/10.21471JAA.S141636 


\section{Prevalence}

There are numerous limitations to quantifying the prevalence of TN allergy. Prevalence reports are often based on self-reported allergy, rather than objective measures, which is often an overestimate. ${ }^{9,10}$ In addition, studies regarding TN allergy often include pollen food allergy syndrome (PFS), otherwise known as oral allergy syndrome, which is characterized by mild oral symptoms, and patients may ingest the TN. ${ }^{11}$ Another barrier to interpreting prevalence studies is that many evaluate allergy generically, querying about "nuts" without specifying which nut, and may include peanut in this category. ${ }^{11}$

Two systematic reviews defined the prevalence of TN allergy while taking these limitations into account. A systematic review by Zuidmeer et $\mathrm{al}^{10}$ reported populationbased cross-sectional and cohort studies published between 1990 and 2006. These studies included prevalence estimates based on self-perception, test results, and oral food challenges (OFCs). Studies performed in clinical settings were excluded to avoid bias. The prevalence of perceived reactions to TNs ranged up to $7.3 \%$. However, most studies included were from Europe where PFS is common. When including only three studies that used OFC as an objective definition of TN allergy, the prevalence ranged from $0.1 \%$ to $4.3 \%$. A more recent systematic review was done by McWilliam et $\mathrm{a}^{11}$ and included studies from 1996 to 2014. Only population-based cross-sectional and cohort studies were included, and studies performed in selected patient groups or in specialty clinic settings were excluded. The majority of studies that were included were regarding children and from Europe. Probable TN allergy was defined as a reported history of an immunoglobulin E (IgE)-mediated reaction occurring $\geq 2$ years ago or self-reports of a doctor's diagnosis of TN allergy. The prevalence of probable allergy ranged from $0.05 \%$ to $4.9 \%$, with only one study providing data on adults. When including seven studies using the gold standard of challenge-confirmed TN allergy, the prevalence ranged from $0 \%$ to $1.6 \%$. In both studies, the prevalence rates were lower when including only challenge-confirmed cases and ranged from $0 \%$ to $4.3 \%$.

The prevalence of allergy to TNs appears to have increased in children. A US nationwide, cross-sectional, random telephone survey was conducted in 2008 , and the results were compared with previous comparable surveys done in 1997 and 2002. ${ }^{12}$ The prevalence of TN allergy in children $<18$ years old increased from $0.2 \%$ in 1997 to $1.1 \%$ in 2008. TN prevalence in adults was $0.5 \%$ in 2008 and was not statistically different between the surveys.
The prevalence of TN allergy varies by region and is higher in children. The US prevalence data based on telephone surveys were mentioned above and were $0.5 \%$ in adults and $1.1 \%$ in children in $2008 .{ }^{12} \mathrm{~A}$ self-reported food allergy survey study conducted in Canada, excluding adults reporting unlikely allergies, estimated a TN allergy prevalence of $1.7 \%$ in children and $1 \%$ in adults. ${ }^{13}$ This was similar to findings in a cross-Canada, random telephone survey, which found prevalence of perceived TN allergy of $1.22 \%$ and probable allergy of $1.14 \% .{ }^{14}$ A European systematic review that included studies from 2000 to 2012 found a pooled estimated prevalence from all age-groups of $1.3 \%$ for self-reported $\mathrm{TN}$ allergy and $0.5 \%$ based on OFC. ${ }^{15} \mathrm{~A}$ study conducted in Australia, which used objective measures for diagnosis, found a prevalence of $2.3 \%$ among schoolchildren aged $10-14$ years. ${ }^{16} \mathrm{~A}$ nationwide, cross-sectional study of Korean schoolchildren found TN prevalence to be $0.32 \% .{ }^{17} \mathrm{~A}$ Mexican study found a prevalence of walnut allergy of $0.4 \%$ in adults. ${ }^{18}$ A questionnaire study done on schoolchildren in Singapore and the Philippines found a prevalence of convincing TN allergy of $0.28 \%$ and $0.3 \%$, respectively. ${ }^{19}$ Overall, TN allergy appears to vary by region, age, and the definition used for diagnosis but affects $\sim 0.05 \%-7.3 \%$ of the population.

\section{Clinical manifestations}

TN allergy typically develops by the age of 2 years, and the number of TNs that a patient is sensitized to can increase with age..$^{20}$ The number of nuts children eat increases with age and can explain the increasing rates of sensitization. ${ }^{20} \mathrm{~A}$ US registry noted that the median age of reaction to TNs was 36 months, compared with peanut, which was 14 months. ${ }^{21}$ Sixty-eight percent of these patients reacted on the first known exposure. ${ }^{21}$ Age of initial reaction to TNs may occur later since children are often exposed to TNs later than to peanut. $^{22}$

Reactions to TNs can be severe. Peanut and TNs account for $70 \%-90 \%$ of reported food-related anaphylactic fatalities, and TNs alone account for $18 \%-40 \%$ of cases of anaphylaxis. ${ }^{23,24}$ Severity of coexisting atopic diseases, including allergic rhinitis, asthma, and eczema, is associated with more severe reactions to TNs. ${ }^{25}$ Asthma may be an independent risk factor to predict severe reactions. ${ }^{21}$

TNs can also cause PFS. PFS is an IgE-mediated allergy due to cross-reacting homologous proteins in pollens and various foods, including nuts, fruits, and vegetables..$^{26}$ The consumption of these foods can cause localized reactions in pollen-sensitized individuals due to cross-reactivity. ${ }^{27}$ In specific, birch-pollen-sensitized individuals may develop PFS upon 
the ingestion of almond and hazelnut. ${ }^{28}$ Symptoms of PFS are usually mild, limited to the oropharynx, and include pruritus, tingling, erythema, and mild edema of the mouth. ${ }^{29}$ Proteins are degraded with digestion due to stomach acid and gastric enzymes, preventing systemic absorption, and reactions rarely progress. ${ }^{30}$

An accidental ingestion of TNs in allergic individuals is frequent. In a 5-year US follow-up telephone survey, including patients with self-reported peanut and $\mathrm{TN}$ allergy, $66 \%$ of individuals had more than five lifetime reactions to peanut or $\mathrm{TN} .{ }^{31}$ In a British study, $15 \%$ of participants had a reaction to $\mathrm{TN}$ and peanut after their initial diagnosis. ${ }^{32}$ In this study, they noted that the subsequent reaction was less severe. This is in contrast to a study by Sicherer et $\mathrm{al}^{21}$ where results showed that progressively more severe reactions occurred with repeat exposures. This study cohort had an overrepresentation of children, and the authors hypothesized that this could have been an age effect, with mild reactors outgrowing the allergy and leaving the patients with a more severe allergy in the cohort of patients with repeat reactions. In addition, older children may report symptoms that are associated with severity (eg, throat tightness). ${ }^{21}$

$\mathrm{TN}$ allergy has a lower likelihood of resolution compared with other food allergies. A study by Fleischer et $\mathrm{al}^{33}$ identified 101 patients in a tertiary care center with TN allergy, defined by a clear clinical history of a $\mathrm{TN}$ reaction as well as confirmatory positive testing. OFCs were offered to participants aged $\geq 4$ years who had a $\mathrm{TN}$ specific-IgE (sIgE) $<10 \mathrm{kU} / \mathrm{L}$ and had no reaction in the past year. Of the 101 patients, 20 participants underwent an OFC and 9 patients passed, demonstrating that only $9 \%$ of $\mathrm{TN}$-allergic patients later became tolerant. This result can be an underestimate as 30 patients who were eligible for an OFC declined. The predictors of outgrowing TN allergies were a low TN SIgE level, a lack of other food or TN allergy, and a history of outgrowing peanut allergy. Of note, patients who developed oral tolerance to peanut may be more likely to choose to undergo a TN OFC, and this criterion can therefore be biased. No patient who passed an OFC had a history of a clinical reaction to two or more TNs, and this may be an indicator of persistent TN allergy. Severity of the initial presenting allergic reaction, a history of asthma, or a history of allergic rhinitis did not predict food challenge outcomes. ${ }^{33}$

\section{Diagnosis}

$\mathrm{TN}$ allergy is diagnosed in the same manner as other food allergies with a combination of a thorough clinical history, serum-specific IgE, skin prick testing (SPT), and OFCs. ${ }^{2,9,34,35}$
Prior history determines clinical suspicion for allergy and helps target testing. Serum and skin tests alone are indicators of sensitization, but the history is a vital component in ascertaining if there is a clinical allergy. ${ }^{9}$ The double-blind, placebo-controlled, food challenge (DBPCFC) remains the gold standard for diagnosis but is not indicated when there is a high clinical suspicion of allergy.

TN-specific skin tests and serum IgE are markers of sensitization and can help aid in the diagnosis when there is clinical suspicion. In a cross-sectional, observational study in the $\mathrm{UK},{ }^{36}$ of 1,000 children and adults referred to an allergy clinic with a history of reaction to TNs or peanut, an SPT of $\geq 8 \mathrm{~mm}$ to TNs predicted clinical reactivity with $>95 \%$ accuracy. An Australian prospective study, ${ }^{37}$ in which 247 patients with concern for TN allergy underwent OFC, confirmed that an SPT $\geq 8$ predicted clinical reactivity for cashew, hazelnut, and walnut. They could not determine the $95 \%$ positive predictive value (PPV) SPT for almond, pistachio, pecan, and Brazil nut and hypothesized that this was due to the small sample size for these nuts. Skin tests can vary widely among patients, institutions, and the extracts used. Therefore, each practitioner must interpret SPT values somewhat cautiously. In regard to TN sIgE, the UK observational study mentioned above found that a level of $\geq 15 \mathrm{kU} / \mathrm{L}$ to an individual TN had a $95 \%$ PPV for clinical allergy. ${ }^{36}$ In the study by Fleischer et al, 63\% patients with $\mathrm{TN}$ sIgE levels of $<2 \mathrm{kU}_{\mathrm{A}} / \mathrm{L}$ passed challenges. ${ }^{33}$ In a retrospective US study reviewing open TN OFCs, 79 of 124 $(89 \%)$ patients passed a challenge with a TN-specific IgE level $<2 \mathrm{kU}_{\mathrm{A}} / \mathrm{L}$, whereas 10 of $16(69 \%)$ patients passed an OFC with a TN sIgE level of $\geq 2 \mathrm{kUA}\left(\right.$ mean $\left.=5.12 \mathrm{kU}_{\mathrm{A}} / \mathrm{L}\right){ }^{38}$ Overall, a SPT $\geq 8 \mathrm{~mm}$ or TN sIgE $\geq 15 \mathrm{kU} / \mathrm{L}$ usually indicates a high risk of allergy.

Component-resolved diagnostics (CRDs), or molecular allergen analysis, are becoming more utilized and may improve accuracy for diagnosing TN allergy. While serumspecific IgE measures IgE to the whole food extract, CRD measures IgE to specific proteins within that food. This can help differentiate sensitization to clinically relevant versus irrelevant proteins and can identify reactivity as a cause for an elevated IgE. ${ }^{39}$ For example, sensitization to an allergen that is resistant to heat or digestion, a stable protein, is more likely to cause systemic reactions. On the other hand, sensitization to proteins that are homologous to aeroallergens and are easily digested may not be clinically relevant. Identifying sensitization to allergen components may elucidate who will have a systemic reaction upon the ingestion of the TN. 
TNs have two major types of proteins, metabolic and storage proteins. The seed storage proteins are the allergens associated with many cases of severe, anaphylactic TN allergy. Seed storage proteins include the prolamin superfamily (including $2 \mathrm{~S}$ albumins) and the cupin superfamily that consists of the legumin-group proteins (the 11S globulins) and vicilins (the $7 \mathrm{~S}$ globulins). ${ }^{40}$ Additional TN proteins, also known as pan-allergens, include lipid transfer proteins (LTPs), profilins (structural proteins), pathogenesis-related proteins, and heveins, and these are similar to proteins in pollens, seeds, fruits, and vegetables and are associated with IgE-mediated cross-reactivity. ${ }^{41}$ Sensitization to these proteins may lead to PFS, although systemic reactions are also possible, particularly for LTP or $2 \mathrm{~S}$ albumins.

\section{Individual TNs}

CRD is available for many individual TNs. Here, we will review prevalence data specific to individual TNs as well as the known component proteins (Table 1).

\section{Hazelnut}

Hazelnut, also known as filbert, is from the genus Corylus and belongs to the Betulaceae, or birch, family. In a systematic chart review, hazelnut was found to be the most common TN allergy in Europe. ${ }^{11}$ However, many studies in this review included PFS reactions to TNs. Hazelnut, along with walnut, was also found to be the most common TN allergy in Spain. ${ }^{42}$ Hazelnut is often consumed in pastries and chocolates. Some hazelnut butters, such as the brand Nutella ${ }^{\circledR}$, are not crosscontaminated with other nuts and therefore may be of interest to patients allergic to a TN other than hazelnut.

$\mathrm{CRD}$ has been useful in differentiating primary hazelnut allergy from sensitization to pan-allergens with homology to birch pollen. Sensitization to the hazelnut components, Cor a 9, an $11 \mathrm{~S}$ globulin; and Cor a 14, a $2 \mathrm{~S}$ albumin, is more specific for hazelnut allergy compared with total hazelnut sIgE..$^{43,44}$ Cor a 9 was detected in $86 \%$ of the patients with hazelnut allergy and a history of systemic reactions. ${ }^{45} \mathrm{~A}$ Dutch study found that an IgE level to Cor a 9 of $\geq 1 \mathrm{kU}_{\mathrm{A}} / \mathrm{L}$ in children and adults or a level to Cor a 14 of $\geq 5 \mathrm{kU}_{\mathrm{A}} / \mathrm{L}$ in children and $\geq 1$ in adults had a specificity of $>90 \%$ in diagnosing hazelnut allergy. ${ }^{46}$ Similar results were found in a US study where a Cor a 9 of $\geq 2.0 \mathrm{kU} / \mathrm{L}$ or Cor a 14 of $\geq 1.0 \mathrm{kU}_{\mathrm{A}} / \mathrm{L}$ had a sensitivity of $92 \%$ and specificity of $93 \%$ for diagnosing clinical reactivity. ${ }^{44}$ Cor a 8 is an LTP that is heat-stable and not cross-reactive to pollen. Sensitization to Cor a 8 is a risk

Table I Individual tree nut components

\begin{tabular}{|c|c|c|c|c|}
\hline Tree nut & Protein family & Component & Protein type & Clinical relevance \\
\hline \multirow[t]{6}{*}{ Hazelnut } & Pan-allergens & Cor a I & PR-10 & Homolog of Bet v I; PFS \\
\hline & & Cor a 2 & Profilin & Homolog of Bet v 2; PFS \\
\hline & & Cor a 8 & LTP & Systemic reactions in children from Mediterranean areas \\
\hline & Storage proteins & Cor a 9 & IIS globulin & Systemic reactions \\
\hline & & Cor a II & 7S globulin & \\
\hline & & Cor a 14 & $2 S$ albumin & Systemic reactions \\
\hline \multirow[t]{3}{*}{ Cashew } & Storage proteins & Ana o I & 7S globulin & \\
\hline & & Ana $\circ 2$ & IIS globulin & \\
\hline & & Ana $\circ 3$ & $2 \mathrm{~S}$ albumin & Systemic reactions \\
\hline \multirow[t]{4}{*}{ Pistachio } & Storage proteins & Pis $\vee \mathrm{I}$ & $2 \mathrm{~S}$ albumin & Homolog of Ana o 3; systemic reactions \\
\hline & & Pis $\vee 2$ & IIS globulin & Homolog of Ana o 2; systemic reactions \\
\hline & & Pis $\vee 3$ & 7S globulin & \\
\hline & & Pis $\vee 5$ & IIS globulin & Homolog of Ana o I \\
\hline \multirow[t]{5}{*}{ Walnut } & Storage proteins & Jug $\mathrm{r} I$ & $2 \mathrm{~S}$ albumin & Systemic reactions \\
\hline & & Jug $r 2$ & 7S globulin & Systemic reactions \\
\hline & & Jug $r 4$ & IIS globulin & Systemic reactions \\
\hline & Pan-allergens & Jug $r 3$ & LTP & Systemic reactions in Mediterranean individuals \\
\hline & & Jug $r 5$ & Profilin & \\
\hline \multirow[t]{3}{*}{ Pecan } & Storage proteins & Car i I & $2 S$ albumin & Homolog of Jug r I \\
\hline & & Car i 2 & 7S globulin & Systemic reactions \\
\hline & & Car i 4 & IIS globulin & Homolog of Jug $r 4$ \\
\hline \multirow[t]{3}{*}{ Almond } & Storage proteins & Pru du 6 & IIS globulin & \\
\hline & Pan-allergens & Pru du 3 & LTP & \\
\hline & & Pru du 4 & Profilin & \\
\hline Pine nut & Storage proteins & Pin $\mathrm{p} I$ & $2 \mathrm{~S}$ albumin & Systemic reactions \\
\hline \multirow[t]{2}{*}{ Brazil nut } & Storage proteins & Ber e I & $2 \mathrm{~S}$ albumin & Systemic reactions \\
\hline & & Ber e 2 & IIS globulin & \\
\hline
\end{tabular}

Abbreviations: LTP, lipid transfer protein; PFS, pollen food syndrome. 
factor for systemic reactions in children from Mediterranean areas. ${ }^{47,48}$ Cor a 1 (PR-10) is a profilin and homolog of Bet v 1 , which is a major birch pollen allergen. Sensitization to Cor a 1 is elevated in patients with PFS to hazelnut. ${ }^{49,50}$ It was found that all patients with PFS to hazelnut were sensitized to Bet v 1 and $>97 \%$ to Cor a 1 , with no patients being sensitized to Cor a 9 or Cor a $8 .{ }^{50}$ Cor a 2 , another profilin, correlates to Bet v 2, which can also cause PFS in patients sensitized to certain birch and grass pollens. ${ }^{51}$ Cor a 11 , a $7 \mathrm{~S}$ vicilin, is less well defined. ${ }^{52}$

\section{Cashew and pistachio}

Cashew and pistachio belong to the Anacardiaceae family and are botanically related. Cosensitization often exists to these nuts. Coallergy often exists as well, although pistachio allergy is somewhat less common, and patients with a cashew or pistachio allergy are often counseled to avoid the related nut. ${ }^{53,54}$ One study showed that cashew nut-sensitized children were cosensitized to pistachio nut in $98 \%$ of cases. They challenged a subset of these patients and found that only $34 \%$ of the cashew-sensitized patients reacted to pistachio. ${ }^{55}$ In another study, all of 42 pistachio-allergic participants had a positive challenge to cashew. ${ }^{54}$

Cashew and pistachio allergies commonly cause severe reactions with very small exposure. In a retrospective chart review including 27 patients with cashew allergy, 74\% experienced anaphylaxis upon cashew ingestion. ${ }^{56}$ In a case-matching study that compared patients who presented primarily for cashew allergy to patients who presented for peanut allergy, more patients in the cashew-allergic group reported wheezing and cardiovascular symptoms, and they required intramuscular adrenaline more frequently. ${ }^{57}$ Interestingly, proteins homologous to cashew may be found in fruit seeds, such as apple and orange, with rare reports of reactions among people with severe cashew allergy if these seeds are eaten. ${ }^{58-60}$

The prevalence of cashew and pistachio nut allergies seems to be common in industrialized countries where these nuts are being used with increasing popularity. Cashew nuts can be found in Asian meals, cakes, and chocolates, and they are being used in commercially prepared pesto sauces. ${ }^{57} \mathrm{In}$ a US registry of patients with TN allergy, which included mostly children, cashew was the second most common cause of TN allergy, and this allergy was found in $20 \%$ of TNallergic patients. ${ }^{21}$ Two other studies also identified cashew, along with walnut, as being the most common TN allergen in the USA. ${ }^{11,33}$ In a 3-year follow-up study involving 139 TN-allergic adults from the Netherlands, $20 \%$ were allergic to cashew, and in France, there was an estimated frequency of $10.3 \%{ }^{61,62}$ Pistachio nut allergy is less prevalent in the USA and was estimated in $7 \%$ of TN-allergic patients. ${ }^{21}$ In Turkey, pistachio allergy was found in $6.7 \%$ of patients with food allergy. ${ }^{63}$

Cashew allergen components include Ana o 1, a vicilin; Ana o 2, a legumin-like 11S globulin; and Ana o 3, a 2S albumin. Sensitization to Ana o 3 is the best predictor of clinical allergy. ${ }^{64}$ In Greek children, IgE sensitization to Ana o 3 was detected in $93 \%$ of cashew-allergic children and in only $6 \%$ of cashew-tolerant patients. ${ }^{65}$ In addition, Ana o 3 can be used to diagnose pistachio allergy. For Ana o 3, an optimal cutoff point of $0.16 \mathrm{kU}_{\mathrm{A}} / \mathrm{L}$ was reported as indicative for cashew nut and pistachio allergies with high sensitivity and specificity. ${ }^{65}$

Pistachio components Pis v 1 (2S albumin) and Pis v 2 (11S globulin) are homologous to Ana o 3 and Ana o 2 , respectively, and have shown to cause sensitization in pistachio-allergic patients. ${ }^{66}$ Of 28 pistachio-allergic patients, $68 \%$ were sensitized to Pis v 1 and $50 \%$ to Pis v $2 .{ }^{66}$ Pis v 3 (7S vicilin) showed correlation with Ana o $1 .{ }^{67} \mathrm{Pis} v 5$ is another $11 \mathrm{~S}$ globulin, but less information is known about this allergen.

\section{Walnut and pecan}

Walnut and pecan are members of the Juglandaceae family, and allergies to these nuts often coexist, with pecan allergy being slightly less common. ${ }^{53}$ Andorf et $\mathrm{al}^{54}$ showed that all participants who were allergic to pecan were also allergic to walnut, while $9 \%$ of walnut-allergic participants tolerated pecan. Walnut is the most common TN allergen among TNallergic patients in Spain and the USA, where it was found to range between $3 \%$ and $34 \% .^{21,33,42}$

Proteins in Juglans regia (English Walnut) include Jug r 1 (2S albumin), Jug r 2 (7S vicilin), Jug r 3 (LTP), Jug r 4 (legumin-like 11S globulin), and Jug r 5 (a profilin). ${ }^{68} \mathrm{Jug}$ r 1 is related to Ana o $3 .^{69}$ Sensitization to Jug r 1 and Jug r 2 was found among $75 \%$ and $60 \%$ of patients with severe clinical presentations, respectively. ${ }^{70,71} \mathrm{Jug} \mathrm{r} 1$ had improved specificity over walnut extract for diagnosing walnut allergy. ${ }^{72}$ Jug $r 4$ was positive in 21 of 37 individuals with walnut allergy $(>57 \%){ }^{73}$ Jug r 3 was recognized in $78.2 \%$ of Italian walnut-allergic patients and may have more importance in Mediterranean patients. However, this study included both patients with PFS and systemic reactions. ${ }^{74}$

Pecan components include Car i 1 (2S albumin) and Car i 4 (11S legumin). ${ }^{75,76}$ These components have been found to be cross-reactive with Jug $r 1$ and Jug r 4. ${ }^{75,76}$ IgE to Car 
i 2, a 7S vicilin, was detected in 6 of 25 patients with pecan allergy confirmed by double-blind, placebo-controlled food challenges. $^{77}$

\section{Almond}

Almond is from the Rosaceae family. In the USA, almond allergy is reported by $9 \%-15 \%$ of TN-allergic individuals. ${ }^{21,33}$ Almond, along with walnut, was the most common TN allergy in allergic individuals in the UK, and the prevalence ranged from $22 \%$ to $33 \%{ }^{11}$ Almonds are often consumed roasted or in almond milk and butters, of which certain brands can be purchased easily without cross-contamination with other nuts. Sensitization to almond correlates strongly with birch sensitization; however, it does not necessarily translate into clinical reactivity. ${ }^{28}$ Almond components, such as Pru du 6(11S globulin), Pru du 3 (LTP), and Pru d 4 (profilin), have been recognized, but little clinical information is available about them.

\section{Pine nut}

Pine nuts, otherwise known as pignoli, are seeds of the Pinaceae family. Pine nuts can be found in salads, Italian dishes such as Italian pesto and pignoli cookies, and Middle Eastern cuisines, such as kibbeh and baklava. Pine nut allergy is less prevalent, and among $\mathrm{TN}$-allergic patients in the USA, $<5 \%$ reported allergy to pine nut. ${ }^{33}$ In a retrospective chart review in Korea, among 126 patients with anaphylaxis to peanut, TNs, and seeds, pine nut allergy accounted for $7 \%$ of the reactions. ${ }^{78}$ However, patients can still be monosensitized to pine nut, and pine nut can trigger severe reactions. ${ }^{79}$ Pine nut allergen Pin $\mathrm{p} 1$ is a $2 \mathrm{~S}$ albumin and was recognized by IgE from 6 of 8 pine nut-allergic patients. ${ }^{80}$

\section{Brazil nut}

Brazil nuts belong to the genus Bertholletia, and they are most often found in mixed nut packages. While in the USA, the prevalence is reported as $<5 \%$, in the UK, the prevalence ranges from $24 \%$ to $33 \%$ among TN individuals. ${ }^{11,33}$ Brazil nut components include Ber e 1 (2S albumin) and Ber e 2 (11S globulin). Sensitization to Ber e 1 showed improved sensitivity over whole extract for the diagnosis of Brazil nut allergy in a small study. ${ }^{81}$

\section{Macadamia and other nuts}

Macadamia nuts are from the Proteaceae family. They are found in baked goods and ice creams. Macadamia nut allergy was reported in $<5 \%$ of US TN-allergic patients. ${ }^{33}$ Case reports of reactions to macadamia nut have been reported, and symptoms range from PFS to severe reactions. ${ }^{82-84}$
Coconut, a drupe, is incorrectly considered a TN. Coconut has demonstrated cross-reactivity with walnut, hazelnut, almond, and macadamia nut in vitro. ${ }^{85-87}$ Despite this, coconut is an uncommon allergen, and allergy to it has not been shown to clinically correlate with TN allergy.

The FDA also listed shea nut as a TN. However, there have been no reported reactions to shea nut. In addition, topical shea butter, which is the common usage of shea nuts, is not allergenic due to its minimal amount of protein; there was undetectable $\operatorname{IgE}$ binding to shea nut found in shea butter extracts by Western blot and enzyme-linked immunosorbent assay. ${ }^{88}$

\section{Coallergy among TNs}

Patients with TN allergy can have cosensitization and coallergy to other TNs. Specific TN allergies coexist more commonly, such as cashew with pistachio as well as walnut with pecan. ${ }^{28,54,89}$ Among 101 individuals in a tertiary care center with TN allergy, $12 \%$ had at least one additional TN allergy. ${ }^{33}$ In a recent study by Couch et al, ${ }^{38} 67$ patients were identified from a US tertiary care center who had a clinical history of TN allergy that were challenged to another TN to which they were sensitized but had not previously ingested. The study found that $76 \%$ passed the OFC. Of note, $90 \%$ of these patients had an $\operatorname{sgE}<2 \mathrm{kU} / \mathrm{L}$ and at least half had a level $<0.35 \mathrm{kU} / \mathrm{L}$. Twenty-five patients had an SPT of at least $3 \mathrm{~mm}$, and $56 \%$ of these passed their OFC. This study was limited by the fact that it was retrospective, the challenges were performed without blinding, and there was a possible preference to perform TN OFCs with little or no sensitization.

\section{Coallergy to peanut}

Peanut is botanically related to legumes and not to TNs, but despite this, reported coallergy between TN and peanut ranges between $20 \%$ and $68 \% .{ }^{20-22,32,33,89}$ Major allergens in peanut have homologs in many TNs; however, these have not been shown to be responsible for clinical reactivity. ${ }^{90}$ Peters et $\mathrm{al}^{91}$ enrolled peanut-allergic patients from the population-based, longitudinal HealthNuts Study and found that, in patients with OFC-proven peanut allergy at the age of 4 years, the TN sensitization rate was $61 \%$ for cashew, almond, or hazelnut. Among 234 patients with physiciandiagnosed peanut allergy, $86 \%$ were sensitized to at least one TN, whereas $34 \%$ had reported clinical allergy. ${ }^{89}$ However, the majority of patients enrolled had never ingested TNs; therefore, this can be an underestimation of clinical allergy. In a US prospective study, 12 of 19 peanut-allergic patients confirmed by DBPCFC had a positive skin test to TNs, but 
all had a negative TN challenge. ${ }^{92}$ In the abovementioned study by Couch et al, ${ }^{38} 46$ patients had peanut allergy and TN sensitization, and $20 \%$ of these patients had a history of clinical allergy to TN. When peanut-allergic patients were challenged to a $\mathrm{TN}$ to which they were sensitized to but had not ingested, 96\% passed their challenge, questioning the previously estimated prevalence of coallergy. However, only 14 of the $68 \mathrm{TN}$ OFCs performed in this group had a $\mathrm{TN}$ sIgE level of at least $2 \mathrm{kU}_{\mathrm{A}} / \mathrm{L}$ and/or an SPT wheal of at least $3 \mathrm{~mm}$. While considering cosensitization and coallergy between peanuts and TNs, many studies point out that select peanut-allergic patients may tolerate TNs, and OFC can be considered.

\section{Management Avoidance}

The two pillars of food allergy management are strict avoidance of the index nut and prompt treatment of symptoms upon accidental exposure. Epinephrine is the first-line treatment for anaphylaxis, and it must be administered promptly for anaphylaxis. Patients with potential anaphylaxis to TNs should have ready access to epinephrine auto-injector in the outpatient setting. ${ }^{93}$

Important components of food avoidance are reading food labels and recognizing the allergen. The Food Allergy Labeling and Consumer Protection Act of 2004 mandates that manufacturers in the USA identify the presence of any of the eight most common food allergens, including TNs. Many companies also choose to add precautionary statements, such as "may contain," or "made in a shared facility," but there is no regulation as to what these mean and consumers do not often recognize this. ${ }^{94}$ Another important component of allergen avoidance is recognizing the food itself, but many people cannot recognize TNs. ${ }^{95,96}$ When 1,105 subjects were shown 19 different pictures of peanuts and TNs, the mean number of correct responses was 8.4. ${ }^{96}$ There was no difference in correct response rate between $\mathrm{TN}$-allergic subjects compared with nonallergic subjects, and only half of the patients with a TN allergy correctly identified all forms of TNs to which they are allergic. ${ }^{96}$

A specific consideration with regard to the management of TN allergy is the decision to avoid all TNs or only the TN to which a patient is clinically allergic (Table 2). Avoiding all nuts simplifies the management. It may also decrease the risk of reactions secondary to cross-contamination or misidentification, which is common as mentioned above. However, it is possible that patients can become sensitized and clinically allergic to TNs during their period of avoidance. The charts of 60 patients who were enrolling for multiple-food oral immunotherapy (OIT) were reviewed, and it was found that TN elimination was often recommended due to concern for cross-contamination of another TN or peanut to which the patient reacted to. ${ }^{97}$ There was a lower rate of clinical reaction to the TNs and higher rate of negative skin test and specific $\mathrm{IgE}$ at the time of diagnosis when compared to peanut, milk, egg, soy, sesame, and wheat. SPT and serum-specific IgE increased significantly over time to TNs, and most OFCs performed later were positive. This suggests that sensitization developed during the period of elimination.

Another approach is to encourage patients to eat the TNs to which they are determined to be clinically tolerant. This decreases unnecessary food avoidance and expands the patient's diet. It may circumvent the observation noted above about increasing sensitization to avoided nuts, but no studies have addressed this possibility. Whether adding the nuts early would "prevent" allergy development is also unknown. The Learning Earning about Peanut Allergy (LEAP) trial showed that in high-risk infants, early introduction of peanut, compared with avoidance, was protective of peanut allergy. ${ }^{98}$ It is not known whether a similar approach to TNs would be protective, but there is a theoretical possibility. Practically speaking, introducing all TNs to infants and toddlers may be limited since whole nuts can be choking hazards and nut spreads or baked good with nuts must be used, and if the dose matters (as it may have for peanut), it could be difficult to achieve a large amount of so many different foods. Studies are needed to determine whether an early feeding prevention approach is safe and effective.

A third approach patients and allergist have taken is to avoid all TNs, except the ones that the patient has already tolerated or selected ones that are easy to obtain without cross-contact. While this approach does not necessarily expand the diet, it simplifies management and decreases the need for OFCs to determine clinical tolerance. The decision to avoid all or select TNs should ultimately involve the patient and their family. Decisions may be influenced by many factors including the patient's age, risk, their developmental ability, and motivation of undertaking OFCs.

\section{Prevention and treatment}

There are currently no data on the primary or secondary prevention of TN allergy. However, available data have changed current recommendations regarding specific avoidance of allergenic foods. In 2000, the American Academy of Pediatrics (AAP) suggested delaying introduction of highly allergenic food in high-risk infants and recommended avoiding peanuts 
Table 2 Alternatives for avoidance in tree nut allergy

\begin{tabular}{|c|c|c|}
\hline Avoidance strategy & Pros & Cons \\
\hline $\begin{array}{l}\text { Eat selected tree } \\
\text { nuts to which they } \\
\text { are clinically tolerant }\end{array}$ & $\begin{array}{l}\text { - Limit unnecessary } \\
\text { food avoidance and } \\
\text { expand the diet } \\
\text { - Possibility that } \\
\text { regular consumption } \\
\text { of an allergenic food } \\
\text { can avoid allergy }\end{array}$ & $\begin{array}{l}\text { - Increase need for } \\
\text { oral food challenges } \\
\text { to assess clinical } \\
\text { tolerance } \\
\text { - Increases risk of } \\
\text { cross-contamination } \\
\text { and misidentification } \\
\text { - Practically must avoid } \\
\text { whole nuts in infants } \\
\text { and toddlers since } \\
\text { they are choking } \\
\text { hazards }\end{array}$ \\
\hline $\begin{array}{l}\text { Avoid all tree nuts } \\
\text { even if clinically } \\
\text { tolerant to select } \\
\text { nuts }\end{array}$ & $\begin{array}{l}\text { - Simplifies } \\
\text { management } \\
\text { - Decreases need for } \\
\text { oral food challenges } \\
\text { to assess clinical } \\
\text { tolerance } \\
\text { - Decreases risk of } \\
\text { cross-contamination } \\
\text { and misidentification }\end{array}$ & $\begin{array}{l}\text { - Concern of } \\
\text { developing } \\
\text { sensitization and } \\
\text { clinical allergy } \\
\text { during the period of } \\
\text { avoidance }\end{array}$ \\
\hline
\end{tabular}

and TNs until the age of 3 years. In 2008, the AAP amended this statement to say there is no current convincing evidence that delaying introduction of allergenic foods had a significant protective effect. ${ }^{99}$ There are no data to delay $\mathrm{TN}$ introduction, and they can be introduced based on family preference in ageappropriate forms. There is no current curative therapy for TN allergy, but approaches being tested such as OIT, sublingual immunotherapy, and epicutaneous immunotherapy could be applicable as research advances. ${ }^{100,101}$

\section{Conclusion}

TN allergy is common, and reactions range from mild itching of the mouth to anaphylaxis. When including only challengeconfirmed cases of TN allergy, prevalence rates ranged up to $4.3 \%$. TNs account for $18 \%-40 \%$ of cases of anaphylaxis. TNs can cause pollen food syndrome in pollen allergic individuals, most commonly to almond and hazelnut in birchallergic individuals. Twelve percent of patients with a TN allergy have at least one additional TN allergy, and specific TN allergies coexist more commonly, such as cashew with pistachio as well as walnut with pecan. Physician-supervised OFCs are needed to differentiate sensitization from clinical allergy. CRDs improve diagnostic accuracy by differentiating sensitization to clinically relevant versus irrelevant proteins. The patient and clinician must decide whether to avoid all TNs or only the ones the patient is clinically allergic to. Risk of cross-contamination and misidentification must be weighed against the benefit of expanding a patient's diet and the possibility of decreasing risk of allergy by consumption. There are no data on primary prevention of TN allergy but, based on data from studies on primary prevention of peanut allergy, delayed introduction is no longer recommended. More studies are needed to find curative therapy for IgEmediated food allergies.

\section{Disclosure}

Tamar Weinberger reports no conflicts of interest in this work. Scott Sicherer receives royalties from UpToDate, a stipend from the American Academy of Allergy, Asthma and Immunology as Associate Editor of the Journal of Allergy and Clinical Immunology in Practice, and his institution receives grants from HAL Allergy Group and the National Institute of Allergy and Infectious Diseases for his research.

\section{References}

1. Stiefel G, Anagnostou K, Boyle RJ, et al. BSACI guideline for the diagnosis and management of peanut and tree nut allergy. Clin Exp Allergy. 2017;47(6):719-739.

2. Sicherer SH, Sampson HA. Food allergy: a review and update on epidemiology, pathogenesis, diagnosis, prevention and management. J Allergy Clin Immunol. 2018;141(1):41-58.

3. Fruit and Tree Nut Yearbook Tables. United States Department of Agriculture Economics, Statistics and Market Information System; 2017. Available from: http://usda.mannlib.cornell.edu/. Accessed Novermber 4, 2017.

4. Blanco Mejia S, Kendall CW, Viguiliouk E, et al. Effect of tree nuts on metabolic syndrome criteria: a systematic review and meta-analysis of randomised controlled trials. BMJ Open. 2014;4(7):e004660.

5. Del Gobbo LC, Falk MC, Feldman R, Lewis K, Mozaffarian D. Effects of tree nuts on blood lipids, apolipoproteins, and blood pressure: systematic review, meta-analysis, and dose-response of 61 controlled intervention trials. Am J Clin Nutr. 2015;102(6):1347-1356.

6. Alasalvar C, Shahidi F. Tree Nuts: Composition, Phytochemicals, and Health Effects. Boca Raton: CRC Press; 2008.

7. Guidance for Industry: Questions and Answers Regarding Food Allergens, including the Food Allergen Labeling and Consumer Protection Act of 2004 (Edition 4); Final Guidance. Available from: https://www. fda.gov/Food. Accessed November 4, 2017.

8. Oria MP, Stallings VA, editors. Finding a Path to Safety in Food Allergy: Assessment of the Global Burden, Causes, Prevention, Management, and Public Policy. Washington, DC: National Academies Press; 2016.

9. Boyce JA, Assa'ad A, Burks AW, et al. Guidelines for the diagnosis and management of food allergy in the United States: summary of the NIAID-sponsored expert panel report. J Allergy Clin Immunol. 2010;126(6):1105-1118.

10. Zuidmeer L, Goldhahn K, Rona RJ, et al. The prevalence of plant food allergies: a systematic review. J Allergy Clin Immunol. 2008;121(5):1210-1218.e4.

11. McWilliam V, Koplin J, Lodge C, Tang M, Dharmage S, Allen K. The prevalence of tree nut allergy: a systematic review. Curr Allergy Asthma Rep. 2015;15(9):54.

12. Sicherer SH, Munoz-Furlong A, Godbold JH, Sampson HA. US prevalence of self-reported peanut, tree nut, and sesame allergy: 11-year follow-up. J Allergy Clin Immunol. 2010;125(6):1322-1326. 
13. Soller L, Ben-Shoshan M, Harrington DW, et al. Overall prevalence of self-reported food allergy in Canada. J Allergy Clin Immunol. 2012;130(4):986-988.

14. Ben-Shoshan M, Harrington DW, Soller L, et al. A population-based study on peanut, tree nut, fish, shellish, and sesame allergy prevalence in Canada. J Allergy Clin Immunol. 2010;125(6):1327-1335.

15. Nwaru BI, Hickstein L, Panesar SS, et al. Prevalence of common food allergies in Europe: a systematic review and meta-analysis. Allergy. 2014;69(8):992-1007.

16. Sasaki M, Koplin JJ, Dharmage SC, et al. Prevalence of clinic-defined food allergy in early adolescence: the SchoolNuts study. J Allergy Clin Immunol. 2018;141(1):391-398.e4.

17. Kim M, Lee JY, Jeon HY, et al. Prevalence of immediate-type food allergy in Korean schoolchildren in 2015: a nationwide, populationbased study. Allergy Asthma Immunol Res. 2017;9(5):410-416.

18. Bedolla-Barajas M, Bedolla-Pulido TR, Camacho-Pena AS, GonzalezGarcia E, Morales-Romero J. Food hypersensitivity in mexican adults at 18 to 50 years of age: a questionnaire survey. Allergy Asthma Immunol Res. 2014;6(6):511-516.

19. Shek LP, Cabrera-Morales EA, Soh SE, et al. A population-based questionnaire survey on the prevalence of peanut, tree nut, and shellfish allergy in 2 Asian populations. J Allergy Clin Immunol. 2010;126(2):324-331, 331.e321-331.e327.

20. Clark AT, Ewan PW. The development and progression of allergy to multiple nuts at different ages. Pediatr Allergy Immunol. 2005;16(6): 507-511.

21. Sicherer SH, Furlong TJ, Munoz-Furlong A, Burks AW, Sampson HA. A voluntary registry for peanut and tree nut allergy: characteristics of the first 5149 registrants. J Allergy Clin Immunol. 2001;108(1):128-132.

22. Sicherer SH, Burks AW, Sampson HA. Clinical features of acute allergic reactions to peanut and tree nuts in children. Pediatrics. 1998;102(1):e6.

23. Bock SA, Munoz-Furlong A, Sampson HA. Fatalities due to anaphylactic reactions to foods. JAllergy Clin Immunol. 2001;107(1):191-193.

24. Bock SA, Munoz-Furlong A, Sampson HA. Further fatalities caused by anaphylactic reactions to food, 2001-2006. JAllergy Clin Immunol. 2007;119(4):1016-1018.

25. Summers CW, Pumphrey RS, Woods CN, McDowell G, Pemberton $\mathrm{PW}$, Arkwright PD. Factors predicting anaphylaxis to peanuts and tree nuts in patients referred to a specialist center. JAllergy Clin Immunol. 2008;121(3):632-638.e632.

26. Valenta R, Kraft D. Type 1 allergic reactions to plant-derived food: a consequence of primary sensitization to pollen allergens. $J$ Allergy Clin Immunol. 1996;97(4):893-895.

27. Osterballe M, Hansen TK, Mortz CG, Bindslev-Jensen C. The clinical relevance of sensitization to pollen-related fruits and vegetables in unselected pollen-sensitized adults. Allergy. 2005;60(2):218-225.

28. Uotila R, Kukkonen AK, Pelkonen AS, Makela MJ. Cross-sensitization profiles of edible nuts in a birch-endemic area. Allergy. 2016;71(4):514-521.

29. Price A, Ramachandran S, Smith GP, Stevenson ML, Pomeranz MK, Cohen DE. Oral allergy syndrome (pollen-food allergy syndrome). Dermatitis. 2015;26(2):78-88.

30. Schimek EM, Zwolfer B, Briza P, et al. Gastrointestinal digestion of Bet v 1-homologous food allergens destroys their mediatorreleasing, but not $\mathrm{T}$ cell-activating, capacity. J Allergy Clin Immunol. 2005;116(6):1327-1333.

31. Sicherer SH, Munoz-Furlong A, Sampson HA. Prevalence of peanut and tree nut allergy in the United States determined by means of a random digit dial telephone survey: a 5-year follow-up study. J Allergy Clin Immunol. 2003;112(6):1203-1207.

32. Ewan PW, Clark AT. Long-term prospective observational study of patients with peanut and nut allergy after participation in a management plan. Lancet. 2001;357(9250):111-115.

33. Fleischer DM, Conover-Walker MK, Matsui EC, Wood RA. The natural history of tree nut allergy. J Allergy Clin Immunol. 2005;116(5):1087-1093.
34. Burks AW, Jones SM, Boyce JA, et al. NIAID-sponsored 2010 guidelines for managing food allergy: applications in the pediatric population. Pediatrics. 2011;128(5):955-965.

35. Sampson HA, Aceves S, Bock SA, et al. Food allergy: a practice parameter update-2014. J Allergy Clin Immunol. 2014;134(5):1016-1025. e1043.

36. Clark AT, Ewan PW. Interpretation of tests for nut allergy in one thousand patients, in relation to allergy or tolerance. Clin Exp Allergy. 2003;33(8):1041-1045.

37. Ho MH, Heine RG, Wong W, Hill DJ. Diagnostic accuracy of skin prick testing in children with tree nut allergy. JAllergy Clin Immunol. 2006;117(6):1506-1508

38. Couch C, Franxman T, Greenhawt M. Characteristics of tree nut challenges in tree nut allergic and tree nut sensitized individuals. Ann Allergy Asthma Immunol. 2017;118(5):591-596.e593.

39. Treudler R, Simon JC. Overview of component resolved diagnostics. Curr Allergy Asthma Rep. 2013;13(1):110-117.

40. Roux KH, Teuber SS, Sathe SK. Tree nut allergens. Int Arch Allergy Immunol. 2003;131(4):234-244.

41. Hauser M, Roulias A, Ferreira F, Egger M. Panallergens and their impact on the allergic patient. Allergy Asthma Clin Immunol. 2010;6(1):1.

42. Haroun-Diaz E, Azofra J, Gonzalez-Mancebo E, et al. Nut allergy in two different areas of Spain: differences in clinical and molecular pattern. Nutrients. 2017;9(8):pii: E909.

43. Eller E, Mortz CG, Bindslev-Jensen C. Cor a 14 is the superior serological marker for hazelnut allergy in children, independent of concomitant peanut allergy. Allergy. 2016;71(4):556-562.

44. Kattan JD, Sicherer SH, Sampson HA. Clinical reactivity to hazelnut may be better identified by component testing than traditional testing methods. J Allergy Clin Immunol Pract. 2014;2(5):633-634.e631.

45. Beyer K, Grishina G, Bardina L, Grishin A, Sampson HA. Identification of an $11 \mathrm{~S}$ globulin as a major hazelnut food allergen in hazelnut-induced systemic reactions. J Allergy Clin Immunol. 2002;110(3):517-523.

46. Masthoff LJ, Mattsson L, Zuidmeer-Jongejan L, et al. Sensitization to Cor a 9 and Cor a 14 is highly specific for a hazelnut allergy with objective symptoms in Dutch children and adults. J Allergy Clin Immunol. 2013;132(2):393-399.

47. Schocker F, Luttkopf D, Scheurer S, et al. Recombinant lipid transfer protein Cor a 8 from hazelnut: a new tool for in vitro diagnosis of potentially severe hazelnut allergy. J Allergy Clin Immunol. 2004;113(1):141-147.

48. Hansen KS, Ballmer-Weber BK, Sastre J, et al. Component-resolved in vitro diagnosis of hazelnut allergy in Europe. J Allergy Clin Immunol. 2009;123(5):1134-1141, 1141.e1131-1141.e1133.

49. Beck SC, Huissoon AP, Collins D, Richter AG, Krishna MT. The concordance between component tests and clinical history in British adults with suspected pollen-food syndrome to peanut and hazelnut. J Clin Pathol. Epub 2017 Aug 5.

50. De Knop KJ, Verweij MM, Grimmelikhuijsen M, et al. Age-related sensitization profiles for hazelnut (Corylus avellana) in a birch-endemic region. Pediatr Allergy Immunol. 2011;22(1 Pt 2):e139-e149.

51. Pastorello EA, Vieths S, Pravettoni V, et al. Identification of hazelnut major allergens in sensitive patients with positive double-blind, placebo-controlled food challenge results. J Allergy Clin Immunol. 2002;109(3):563-570.

52. Lauer I, Foetisch K, Kolarich D, et al. Hazelnut (Corylus avellana) vicilin Cor a 11: molecular characterization of a glycoprotein and its allergenic activity. Biochem J. 2004;383(Pt 2):327-334.

53. Goetz DW, Whisman BA, Goetz AD. Cross-reactivity among edible nuts: double immunodiffusion, crossed immunoelectrophoresis, and human specific IgE serologic surveys. Ann Allergy Asthma Immunol. 2005;95(1):45-52.

54. Andorf S, Borres MP, Block W, et al. Association of clinical reactivity with sensitization to allergen components in multifood-allergic children. J Allergy Clin Immunol Pract. 2017;5(5):1325-1334.e1324. 
55. van der Valk JPM, Bouche RE, Gerth van Wijk R, et al. Low percentage of clinically relevant pistachio nut and mango co-sensitisation in cashew nut sensitised children. Clin Transl Allergy. 2017;7:8.

56. Davoren M, Peake J. Cashew nut allergy is associated with a high risk of anaphylaxis. Arch Dis Child. 2005;90(10):1084-1085.

57. Clark AT, Anagnostou K, Ewan PW. Cashew nut causes more severe reactions than peanut: case-matched comparison in 141 children. Allergy. 2007;62(8):913-916.

58. Turner PJ, Gray PE, Wong M, et al. Anaphylaxis to apple and orange seed. J Allergy Clin Immunol. 2011;128(6):1363-1365.

59. Wang ET. Anaphylaxis caused by tangerine seeds but not tangerine fruit. Ann Allergy Asthma Immunol. 2008;101(5):553-554.

60. O'Sullivan MD, Somerville C. Cosensitization to orange seed and cashew nut. Ann Allergy Asthma Immunol. 2011;107(3):282-283.

61. Le TM, Lindner TM, Pasmans SG, et al. Reported food allergy to peanut, tree nuts and fruit: comparison of clinical manifestations, prescription of medication and impact on daily life. Allergy. 2008;63(7):910-916.

62. Moneret-Vautrin DA. Épidémiologie de l'allergie alimentaire [Epidemiology of food allergies]. Revue française d'allergologie et d'immunologie clinique. 2008;48:171-178. French.

63. Kaya A, Erkocoglu M, Civelek E, Cakir B, Kocabas CN. Prevalence of confirmed IgE-mediated food allergy among adolescents in Turkey. Pediatr Allergy Immunol. 2013;24(5):456-462.

64. Lange L, Lasota L, Finger A, et al. Ana o 3-specific IgE is a good predictor for clinically relevant cashew allergy in children. Allergy. 2017;72(4):598-603.

65. Savvatianos S, Konstantinopoulos AP, Borga A, et al. Sensitization to cashew nut $2 \mathrm{~S}$ albumin, Ana o 3 , is highly predictive of cashew and pistachio allergy in Greek children. J Allergy Clin Immunol. 2015;136(1):192-194.

66. Ahn K, Bardina L, Grishina G, Beyer K, Sampson HA. Identification of two pistachio allergens, Pis $\vee 1$ and Pis $v 2$, belonging to the $2 \mathrm{~S}$ albumin and 11S globulin family. Clin Exp Allergy. 2009;39(6):926-934.

67. Willison LN, Tawde P, Robotham JM, et al. Pistachio vicilin, Pis v 3, is immunoglobulin E-reactive and cross-reacts with the homologous cashew allergen, Ana o 1. Clin Exp Allergy. 2008;38(7):1229-1238.

68. Costa J, Carrapatoso I, Oliveira MB, Mafra I. Walnut allergens: molecular characterization, detection and clinical relevance. Clin Exp Allergy. 2014;44(3):319-341.

69. Robotham JM, Wang F, Seamon V, et al. Ana o 3, an important cashew nut (Anacardium occidentale L.) allergen of the $2 \mathrm{~S}$ albumin family. $J$ Allergy Clin Immunol. 2005;115(6):1284-1290.

70. Teuber SS, Dandekar AM, Peterson WR, Sellers CL. Cloning and sequencing of a gene encoding a $2 \mathrm{~S}$ albumin seed storage protein precursor from English walnut (Juglans regia), a major food allergen. J Allergy Clin Immunol. 1998;101(6 Pt 1):807-814.

71. Teuber SS, Jarvis KC, Dandekar AM, Peterson WR, Ansari AA. Identification and cloning of a complementary DNA encoding a vicilin-like proprotein, jug r 2, from English walnut kernel (Juglans regia), a major food allergen. J Allergy Clin Immunol. 1999;104(6):1311-1320.

72. Mew R, Borres M, Sjolander S, du Toit G. A retrospect study into the utility of allergen components in walnut allergy. Pediatr Allergy Immunol. 2016;27(7):750-752.

73. Wallowitz M, Peterson WR, Uratsu S, Comstock SS, Dandekar AM, Teuber SS. Jug r 4, a legumin group food allergen from walnut (Juglans regia Cv. Chandler). J Agric Food Chem. 2006;54(21):8369-8375.

74. Pastorello EA, Farioli L, Pravettoni V, et al. Lipid transfer protein and vicilin are important walnut allergens in patients not allergic to pollen. J Allergy Clin Immunol. 2004;114(4):908-914.

75. Sharma GM, Irsigler A, Dhanarajan P, et al. Cloning and characterization of an 11S legumin, Car i 4, a major allergen in pecan. J Agric Food Chem. 2011;59(17):9542-9552.

76. Sharma GM, Irsigler A, Dhanarajan P, et al. Cloning and characterization of $2 \mathrm{~S}$ albumin, Car i 1, a major allergen in pecan. J Agric Food Chem. 2011;59(8):4130-4139.
77. Zhang Y, Lee B, Du WX, et al. Identification and characterization of a new pecan [Carya illinoinensis (Wangenh.) K. Koch] allergen, Car i 2. JAgric Food Chem. 2016;64(20):4146-4151.

78. Jeong K, Lee SY, Ahn K, et al. A multicenter study on anaphylaxis caused by peanut, tree nuts, and seeds in children and adolescents. Allergy. 2017;72(3):507-510.

79. Cabanillas B, Cheng H, Grimm CC, et al. Pine nut allergy: clinical features and major allergens characterization. Mol Nutr Food Res. 2012;56(12):1884-1893.

80. Cabanillas B, Crespo JF, Maleki SJ, Rodriguez J, Novak N. Pin p 1 is a major allergen in pine nut and the first food allergen described in the plant group of gymnosperms. Food Chem. 2016;210:70-77.

81. Rayes H, Raza AA, Williams A, Matthews S, Arshad SH. Specific $\mathrm{IgE}$ to recombinant protein (Ber e 1) for the diagnosis of Brazil nut allergy. Clin Exp Allergy. 2016;46(4):654-656.

82. Knott E, Gurer CK, Ellwanger J, Ring J, Darsow U. Macadamia nut allergy. J Eur Acad Dermatol Venereol. 2008;22(11):1394-1395.

83. De Knop KJ, Hagendorens MM, Bridts CH, Stevens WJ, Ebo DG. Macadamia nut allergy: 2 case reports and a review of the literature. Acta Clin Belg. 2010;65(2):129-132.

84. Inaba Y, Yagami A, Suzuki K, Matsunaga K. [Allergy to macadamia nut]. Arerugi. 2007;56(7):699-702. Japanese.

85. Nguyen SA, More DR, Whisman BA, Hagan LL. Cross-reactivity between coconut and hazelnut proteins in a patient with coconut anaphylaxis. Ann Allergy Asthma Immunol. 2004;92(2):281-284.

86. Polk BI, Dinakarpandian D, Nanda M, Barnes C, Dinakar C. Association of tree nut and coconut sensitizations. Ann Allergy Asthma Immunol. 2016;117(4):412-416.

87. Teuber SS, Peterson WR. Systemic allergic reaction to coconut (Cocos nucifera) in 2 subjects with hypersensitivity to tree nut and demonstration of cross-reactivity to legumin-like seed storage proteins: new coconut and walnut food allergens. J Allergy Clin Immunol. 1999;103(6):1180-1185.

88. Chawla KK, Bencharitiwong R, Ayuso R, Grishina G, Nowak-Wegrzyn A. Shea butter contains no IgE-binding soluble proteins. J Allergy Clin Immunol. 2011;127(3):680-682.

89. Maloney JM, Rudengren M, Ahlstedt S, Bock SA, Sampson HA. The use of serum-specific IgE measurements for the diagnosis of peanut, tree nut, and seed allergy. J Allergy Clin Immunol. 2008;122(1):145-151.

90. de Leon MP, Glaspole IN, Drew AC, Rolland JM, O'Hehir RE, Suphioglu C. Immunological analysis of allergenic cross-reactivity between peanut and tree nuts. Clin Exp Allergy. 2003;33(9):1273-1280.

91. Peters RL, Allen KJ, Dharmage SC, et al. Natural history of peanut allergy and predictors of resolution in the first 4 years of life: a population-based assessment. J Allergy Clin Immunol. 2015;135(5):12571266.e1251-e1252.

92. Bock SA, Atkins FM. The natural history of peanut allergy. J Allergy Clin Immunol. 1989;83(5):900-904.

93. Kastner M, Harada L, Waserman S. Gaps in anaphylaxis management at the level of physicians, patients, and the community: a systematic review of the literature. Allergy. 2010;65(4):435-444.

94. Marchisotto MJ, Harada L, Kamdar O, et al. Food allergen labeling and purchasing habits in the United States and Canada. JAllergy Clin Immunol Pract. 2017;5(2):345-351.e342.

95. Ferdman RM, Church JA. Mixed-up nuts: identification of peanuts and tree nuts by children. Ann Allergy Asthma Immunol. 2006;97(1):73-77.

96. Hostetler TL, Hostetler SG, Phillips G, Martin BL. The ability of adults and children to visually identify peanuts and tree nuts. Ann Allergy Asthma Immunol. 2012;108(1):25-29.

97. Elizur A, Bollyky JB, Block WM. Elimination diet and the development of multiple tree-nut allergies. Pediatr Res. 2017;82(4): 671-677.

98. Du Toit G, Roberts G, Sayre PH, et al. Randomized trial of peanut consumption in infants at risk for peanut allergy. N Engl J Med. 2015; 372(9):803-813. 
99. Greer FR, Sicherer SH, Burks AW; American Academy of Pediatrics Committee on Nutrition; American Academy of Pediatrics Section on Allergy and Immunology. Effects of early nutritional interventions on the development of atopic disease in infants and children: the role of maternal dietary restriction, breastfeeding, timing of introduction of complementary foods, and hydrolyzed formulas. Pediatrics. 2008;121(1):183-191.
100. Keet CA, Wood RA. Emerging therapies for food allergy. J Clin Invest. 2014;124(5):1880-1886.

101. Pesek RD, Jones SM. Current and emerging therapies for IgE-mediated food allergy. Curr Allergy Asthma Rep. 2016;16(4):28.

\section{Publish your work in this journal}

The Journal of Asthma and Allergy is an international, peer-reviewed open access journal publishing original research, reports, editorials and commentaries on the following topics: Asthma; Pulmonary physiology; Asthma related clinical health; Clinical immunology and the immunological basis of disease; Pharmacological interventions and

\section{Dovepress}

new therapies. This journal is included in PubMed. The manuscript management system is completely online and includes a very quick and fair peer-review system, which is all easy to use. Visit http://www. dovepress.com/testimonials.php to read real quotes from published authors.

Submit your manuscript here: https://www.dovepress.com/journal-of-asthma-and-allergy-journal 